\title{
Pertumbuhan dan Kandungan Minyak Atsiri Tanaman Selasih (Ocimum basilicum L.) pada Naungan dan Dosis Pupuk Fosfat yang Berbeda
}

\author{
Growth and Essential Oil Content of Basil (Ocimum basilicum L.) \\ on Different Shading and Phosphate Fertilizers Rate
}

\author{
Diana Nurus Sholehah*, Suhartono, dan Angga Lesmana \\ Program Studi Agroteknologi, Fakultas Pertanian, Universitas Trunojoyo Madura \\ Jl. Raya Telang PO BOX 2, Telang Kamal Bangkalan Madura, Indonesia
}

Diterima 21 Maret 2018/Disetujui 4 Juli 2018

\begin{abstract}
Basil (Ocimum basilicum L.) is a plant that has great potency to be developed. Almost all parts of the plant can be utilized. This study aimed to determine the effect of shade and phosphate fertilizer on growth and essential oil content in basil. This research was conducted at the experimental field of Agrotechnology Departement, Faculty of Agriculture, University of Trunojoyo Madura, during January-April 2015. The research was arranged in a split plot design with 3 replications. Main plot was shading i.e., without shading and $25 \%$ shading. The subplots were phosphate fertilizer rate, i.e., 0, 1.5, 3.0, and 4.5 $g$ SP36 per plant that was planted in polybags. The results showed that plants treated with $25 \%$ of shading and applied with phosphate $3 \mathrm{~g}$ per plant had the highest total dry weight, production of essential oil and eugenol. Shading of $25 \%$ give the best results on plant height, leaf area and total fresh weight of the plant. Application of phosphate fertilizer $3 \mathrm{~g}$ per plant give the highest content of chlorophyll (chlorophyll $b$ and total chlorophyll), while the highest essential oil and eugenol content of leaves is obtained from application of phosphate fertilizer 3 and $4.5 \mathrm{~g}$ per plant. Shading and phosphate fertilizer application did not affect leaf number.
\end{abstract}

Keywords: chlorophyll, eugenol, leaf, phenylpropanoids, production

\section{ABSTRAK}

Selasih (Ocimum basilicum L.) adalah tanaman yang memiliki banyak manfaat sehingga berpotensi besar untuk dikembangkan secara luas. Hampir semua bagian tanaman dapat dimanfaatkan. Penelitian ini bertujuan untuk mengetahui pengaruh naungan dan pupuk fosfat terhadap pertumbuhan dan kandungan bioaktif tanaman selasih (Ocimum basilicum L.). Penelitian ini dilakukan di Kebun Percobaan Program Studi Agroekoteknologi, Fakultas Pertanian, Universitas Trunojoyo Madura pada bulan Januari-April 2015. Penanaman dilakukan dalam polybag. Rancangan yang digunakan yaitu petak terbagi. Petak utama adalah naungan yang terdiri atas 2 taraf yaitu tanpa naungan (0\%) dan naungan $25 \%$. Anak petak adalah pupuk fosfat yang terdiri atas 4 taraf yaitu 0, 1.5, 3.0, dan $4.5 \mathrm{~g}$ SP36 per tanaman. Hasil penelitian menunjukkan bahwa interaksi perlakuan naungan 25\% dan pupuk fosfat $3 \mathrm{~g}$ per tanaman memberikan hasil tertinggi pada bobot kering total tanaman, produksi minyak atsiri dan eugenol per tanaman. Naungan $25 \%$ menghasilkan nilai tertinggi pada variabel tinggi tanaman, luas daun dan bobot basah total tanaman. Perlakuan pupuk fosfat $3 \mathrm{~g}$ SP36 per tanaman memberikan nilai tertinggi pada kandungan klorofil (klorofil b dan klorofil total), sedangkan kadar minyak atsiri dan eugenol daun tertinggi diperoleh dari perlakuan pupuk fosfat $3 \mathrm{~g}$ dan $4.5 \mathrm{~g}$ SP36 per tanaman. Perlakuan naungan dan pupuk fosfat tidak berpengaruh terhadap jumlah daun.

Kata kunci: daun, eugenol, fenilpropanoid, klorofil, produksi

\section{PENDAHULUAN}

Tanaman selasih (Ocimum basilicum L.) adalah tanaman yang memiliki banyak manfaat sehingga berpotensi besar untuk dikembangkan secara luas. Hampir semua bagian

\footnotetext{
* Penulis untuk korespondensi. e-mail: diananurus@yahoo.co.id
}

tanaman dapat dimanfaatkan mulai dari biji, bunga, hingga daun (Hadipoentyanti dan Wahyuni, 2008). Seluruh bagian tanaman yang berada di atas permukaan tanah mengandung minyak atsiri sebagai komponen utama serta komponen lainnya seperti tanin, kardiak glikosida, flavonoid dan senyawa fenolik lainnya serta saponin. Minyak atsiri selasih telah terbukti memiliki efek imunomodulator, hiperglikemia, hipolipidemia, antiinflamasi, hepatoprotektif, antimutagen, 
antimikroba, antivirus, antioksidan, efek terhadap sistem syaraf serta memiliki kemampuan sebagai biopestisida sebagai penolak serangga dan larvasida (Kardinan, 2009; Khair-ul-Bariyah, 2012).

Selasih adalah tanaman liar yang dapat tumbuh pada ketinggian 0-1500 mdpl pada intensitas cahaya matahari penuh maupun ternaungi (Hadipoentyanti dan Wahyuni, 2008). Menurut Ekawati et al. (2010), naungan dapat mempengaruhi morfologi sayuran indigenous di bawah tegakan seperti tinggi tanaman, jumlah daun serta panjang dan lebar daun sehingga berpengaruh pula terhadap berat basah, berat kering dan produktivitas tanaman. Cahaya matahari Dapat berpengaruh terhadap produksi minyak atsiri secara langsung dengan mempengaruhi jalur metabolismenya dan secara tidak langsung dengan meningkatkan produksi biomassa tanaman sumber minyak atsiri (Feijo et al., 2014). Informasi yang memadai mengenai intensitas cahaya matahari yang tepat diperlukan untuk memperoleh pertumbuhan dan produksi selasih yang optimal.

Fosfor berperan penting dalam sel dengan menyusun membran sel tanaman dan membentuk molekul berenergi tinggi untuk metabolisme primer maupun sekunder tanaman yaitu ATP (Hopkins dan Huner, 2008). Makromolekul sel seperti DNA dan RNA yang berperan untuk membentuk enzim dalam biosintesa metabolisme sekunder juga terbentuk dari fosfor (Agusta, 2006; Gang et al., 2001). Hal ini terbukti pada penelitian sebelumnya, perlakuan pupuk fosfor pada dosis $1.6 \mathrm{~g}$ per pot pada keadaan cekaman air mampu memperbaiki penurunan laju fotosintesis dan pertumbuhan tanaman sehingga dapat meningkatkan berat basah dan kandungan minyak atsiri Dracocephalum maldovica L. (Hani et al., 2015). Aplikasi pupuk P pada tanaman Monarda dydima juga dapat meningkatkan kandungan minyak atsiri, tinggi tanaman dan berat akar (Naseri et al., 2011).

Naungan dan aplikasi pupuk fosfat yang tepat dapat dipertimbangkan sebagai teknik budidaya dalam usaha meningkatkan kandungan minyak atsiri pada tanaman selasih. Penelitian ini bertujuan untuk mendapatkan informasi mengenai pengaruh naungan dan aplikasi pupuk fosfat terhadap pertumbuhan dan kandungan minyak atsiri pada tanaman selasih.

\section{BAHAN DAN METODE}

Penelitian dilaksanakan di Kebun Percobaan Program Studi Agroekoteknologi, Fakultas Pertanian, Universitas Trunojoyo Madura di Desa Telang, Kecamatan Kamal, Kabupaten Bangkalan, Madura, pada ketinggian $5 \mathrm{~m}$ dpl. Penelitian ini dilaksanakan pada bulan Januari-April 2015.

Penanaman dilakukan dalam polybag ukuran $40 \mathrm{~cm} \mathrm{x}$ $40 \mathrm{~cm}$. Spektrofotometer UV-Vis digunakan untuk analisis kandungan klorofil dan eugenol. Bahan yang digunakan dalam penelitian ini adalah biji tanaman selasih yang diperoleh dari daerah Malang, Jawa Timur. Media tanam yang digunakan berupa tanah dan kompos.

Penelitian ini disusun menggunakan rancangan petak terbagi (split plot design). Intensitas naungan sebagai petak utama terdiri atas dua taraf yaitu tanpa naungan $(0 \%)$ dan naungan $25 \%$ menggunakan paranet. Sebagai anak petak adalah pupuk fosfat yaitu menggunakan pupuk SP36 yang terdiri atas empat taraf dosis yaitu $0,1.5,3.0$, dan $4.5 \mathrm{~g}$ per tanaman. Pupuk fosfat diberikan 1 kali yaitu pada saat tanam dan diberikan dengan cara tugal. Penelitian dilakukan dengan tiga ulangan, setiap ulangan terdiri atas tiga tanaman. Biji selasih disemaikan pada media yang mengandung tanah dan pupuk kompos dengan perbandingan 2:1. Bibit selasih yang telah berumur tiga minggu dan memiliki lima helai daun dipindahkan ke dalam polibag berukuran $40 \mathrm{~cm} \mathrm{x}$ $40 \mathrm{~cm}$ berisi media yang sama dengan media semai, dan diletakkan di lahan dengan jarak antar polibag yaitu $30 \mathrm{~cm}$ x $40 \mathrm{~cm}$. Pemupukan menggunakan pupuk fosfat sesuai perlakuan pada saat pindah tanam dengan cara dibenamkan pada lubang yang dibuat dengan jarak $5 \mathrm{~cm}$ dari lubang tanam. Panen dilakukan setelah tanaman berbunga penuh, mulai membentuk biji, dan daun bagian bawah berwarna kekuningan namun belum gugur (Hadipoentyanti dan Wahyuni, 2008). Data yang diamati adalah karakter morfologi, klorofil, produktivitas tanaman dan kandungan bioaktif. Karakter morfologi yang diamati meliputi tinggi tanaman yang diukur dari pangkal batang hingga ujung daun terpanjang, jumlah daun yang telah membuka sempurna dan luas daun total tanaman. Kandungan klorofil diukur menggunakan spektrofotometer meliputi klorofil a, b, dan klorofil total sesuai metode Harborne (1987). Produktivitas tanaman yang diamati meliputi bobot basah total tanaman, bobot kering total tanaman. Kandungan bioaktif yang diamati meliputi minyak atsiri dan eugenol. Minyak atsiri diperoleh dengan cara destilasi uap pada daun yang telah dikeringkan dengan cara kering angin kemudian dihitung kandungan eugenolnya menggunakan spektrofotometer (Wahyuni et al., 2005).

Seluruh data yang diperoleh dianalisis dengan menggunakan analisis ragam, dan apabila berpengaruh nyata dilanjutkan dengan uji Beda Nyata Terkecil (BNT) taraf 5\%.

\section{HASIL DAN PEMBAHASAN}

\section{Kondisi Umum}

Intensitas sinar matahari harian pada petak tanpa naungan berkisar antara 13.170-104,866.6 lux sedangkan pada petak naungan $25 \%$ berkisar antara 4,054.7-31,350.7 lux. Naungan menyebabkan perbedaan waktu munculnya bunga. Tanaman selasih tanpa naungan berbunga pada umur 42 HST, sedangkan dengan naungan berbunga pada umur $72 \mathrm{HST}$, hal ini menyebabkan panen tidak dilakukan bersamaan. Selasih tanpa naungan dipanen pada umur 70 HST, sedangkan dengan naungan dipanen pada umur 98 HST.

\section{Karakter Morfologi}

Hasil analisis menunjukkan bahwa tidak terdapat pengaruh interaksi perlakuan naungan dan pupuk fosfat 
terhadap karakter morfologi selasih. Naungan berpengaruh nyata terhadap tinggi tanaman dengan nilai tertinggi yaitu $97.5 \mathrm{~cm}$ diperoleh dari perlakuan naungan $25 \%$, sedangkan perlakuan pupuk fosfat tidak berpengaruh pada tinggi tanaman (Tabel 1). Nilai ini mendekati tinggi tanaman aksesi selasih asal Bogor yaitu $97.89 \mathrm{~cm}$ (Hadipoentyanti dan Wahyuni, 2008). Auksin akan berpindah menuju bagian yang ternaungi dan mengaktifkan zona elongasi sehingga menyebabkan akselerasi tinggi tanaman pada bagian yang ternaungi (Taiz dan Zeiger, 2006).

Perlakuan naungan berpengaruh nyata terhadap luas daun sedangkan perlakuan pupuk fosfat tidak berpengaruh terhadap luas daun (Tabel 1). Luas daun yang dihasilkan oleh naungan $25 \%$ lebih tinggi daripada tanpa naungan. Hal ini sejalan dengan hasil penelitian Musyarofah et al. (2007) pada tanaman pegagan dengan taraf naungan $65 \%$ memiliki luas daun lebih besar dibandingkan taraf naungan 55\%. Daun adalah organ tanaman yang berperan dalam fotosintesa. Perubahan intensitas sinar matahari akan mempengaruhi kecepatan fotosintesis sehingga mendorong daun melakukan adaptasi salah satunya pada bagian mesofil dan epidermis.
Pada keadaan ternaungi, daun menjadi lebih luas dan tipis. Hal ini terjadi akibat lapisan mesofilnya mengandung lapisan palisade yang lebih tipis dan memiliki sel yang berukuran lebih kecil. Tanaman siofita yaitu tanaman yang toleran pada cahaya rendah, sel mesofil beradaptasi dengan memiliki sel palisade berbentuk oval atau kerucut serta mengandung lebih banyak lapisan bunga karang. Bagian epidermis mengandung lapisan lilin, kutikula dan trikoma yang lebih sedikit (Kisman et al., 2007, Khrolenko et al., 2012).

\section{Kandungan Klorofil}

Hasil penelitian menunjukkan bahwa tidak terdapat interaksi perlakuan naungan dan pupuk fosfat terhadap kandungan klorofil. Perbedaan kandungan klorofil terjadi pada klorofil $\mathrm{b}$ dan klorofil total akibat perlakuan pupuk $\mathrm{P}$ (Tabel 2). Nilai tertinggi diperoleh pada perlakuan pupuk fosfat $3.0 \mathrm{~g}$ SP36 per tanaman. Hal ini sejalan dengan hasil penelitian Suntoro et al. (2014) yang menunjukkan bahwa unsur fosfor dalam abu vulkanik dan pupuk kandang diduga

Tabel 1. Karakter agronomi dan bobot basah total tanaman selasih akibat perlakuan naungan dan pupuk fosfat pada umur 63 HST

\begin{tabular}{lcccc}
\hline Perlakuan & $\begin{array}{c}\text { Tinggi tanaman } \\
(\mathrm{cm})\end{array}$ & $\begin{array}{c}\text { Luas daun total } \\
\left(\mathrm{cm}^{2}\right)\end{array}$ & $\begin{array}{c}\text { Jumlah daun } \\
(\text { helai })\end{array}$ & $\begin{array}{c}\text { Bobot basah total } \\
\text { tanaman }(\mathrm{g})\end{array}$ \\
\hline Tanpa naungan & $64.1 \mathrm{~b}$ & $9,187.8 \mathrm{~b}$ & 968.8 & $202.8 \mathrm{~b}$ \\
Naungan 25\% & $97.5 \mathrm{a}$ & $19,655.8 \mathrm{a}$ & $1,079.1$ & $351.6 \mathrm{a}$ \\
\hline BNT 5\% & 3.5 & 510.9 & - & 77.1 \\
\hline Pupuk 0 g SP36 & 81.8 & $13,857.7$ & 985.0 & 285.0 \\
Pupuk 1.5 g SP36 & 81.3 & $13,757.9$ & $1,009.2$ & 283.5 \\
Pupuk 3.0 g SP36 & 80.5 & $15,188.8$ & $1,067.0$ & 273.5 \\
Pupuk 4.5 g SP36 & 79.5 & $14,882.8$ & $1,034.7$ & 266.8 \\
\hline BNT 5\% & - & - & - & - \\
\hline
\end{tabular}

Keterangan: Angka-angka yang diikuti huruf yang sama pada kolom yang sama menunjukkan tidak berbeda nyata berdasarkan uji BNT $5 \%$

Tabel 2. Kandungan klorofil tanaman akibat perlakuan naungan dan pupuk fosfat

\begin{tabular}{lccc}
\hline Perlakuan & $\begin{array}{c}\text { Klorofil a } \\
\left(\mathrm{mg} \mathrm{L}^{-1}\right)\end{array}$ & $\begin{array}{c}\text { Klorofil b } \\
\left(\mathrm{mg} \mathrm{L}^{-1}\right)\end{array}$ & $\begin{array}{c}\text { Klorofil total } \\
\left(\mathrm{mg} \mathrm{L}^{-1}\right)\end{array}$ \\
\hline Tanpa naungan & 3.1 & 4.5 & 7.6 \\
Naungan 25\% & 7.1 & 4.0 & 11.1 \\
\hline BNT 5\% & - & - & - \\
\hline Pupuk 0 g SP36 & 4.6 & $2.9 \mathrm{~b}$ & $7.5 \mathrm{~b}$ \\
Pupuk 1.5 g SP36 & 5.4 & $3.2 \mathrm{ab}$ & $8.5 \mathrm{ab}$ \\
Pupuk 3.0 g SP36 & 6.2 & $4.3 \mathrm{a}$ & $10.5 \mathrm{a}$ \\
Pupuk 4.5 g SP36 & 4.2 & $2.3 \mathrm{~b}$ & $6.5 \mathrm{~b}$ \\
\hline BNT 5\% & - & 1.697 & 2.651 \\
\hline
\end{tabular}

Keterangan: Angka-angka yang diikuti huruf yang sama pada kolom yang sama menunjukkan tidak berbeda nyata berdasarkan uji BNT $5 \%$ 
berperan meningkatkan kandungan klorofil total jagung. Defisiensi fosfor dapat menurunkan kecepatan fotosintesis pada tanaman padi (Xu et al., 2007). Fosfor berperan penting dalam proses fotosintesis sebagai penyusun fosfolipida kloroplas dan berperan dalam jalur metabolisme pembentukan porfirin maupun klorofil secara langsung (Hopkins dan Huner, 2008).

\section{Produktivitas Tanaman}

Tabel 1 menunjukkan tidak terdapat interaksi antara naungan dengan pupuk fosfat pada rata-rata bobot basah total tanaman. Perlakuan naungan 25\% meningkatkan bobot basah total tanaman secara nyata sedangkan perlakuan pupuk fosfat tidak berpengaruh nyata. Adaptasi morfologi tanaman pada intensitas sinar matahari yang berbeda untuk mempertahankan kapasitas fotosintesis mengakibatkan perubahan akumulasi bahan organik dan biomassa (Devkota dan Jha, 2010). Naungan 25\% menyebabkan tinggi tanaman dan luas daun tertinggi sehingga menghasilkan berat basah total tanaman lebih tinggi dibandingkan tanpa naungan.

Interaksi perlakuan naungan dengan pupuk fosfat berpengaruh terhadap bobot kering total tanaman (Tabel 3). Hasil terbaik terjadi pada perlakuan naungan $25 \%$ dengan pupuk fosfat $3.0 \mathrm{~g}$ SP36 per tanaman yaitu $147.70 \mathrm{~g}$ per tanaman. Bobot kering yang lebih tinggi menunjukkan akumulasi fotosintat yang lebih tinggi. Sinar matahari memiliki pengaruh besar dalam pengaturan fotosintesis dan pertumbuhan tanaman dibandingkan faktor lingkungan yang lain. Peningkatan fotosintesis perlu didukung ketersediaan nutrisi yang cukup salah satunya fosfat (Cheng et al., 2014, Li et al., 2014).

\section{Kadar Bioaktif}

Produksi minyak atsiri dan eugenol tanaman selasih yang dihitung dari perkalian bobot kering daun dengan kadar minyak atsiri dan eugenol dipengaruhi oleh interaksi perlakuan naungan dan pupuk fosfat. Hasil terbaik diperoleh dari naungan 25\% dan 3.0 g SP36 per tanaman (Tabel 3). Minyak atsiri selasih ini termasuk tipe eugenol karena mengandung eugenol sebagai komponen utama (Wahyuni et al., 2005). Eugenol adalah salah satu jenis metabolit sekunder golongan fenilpropanoid yang sintesisnya akan meningkat jika tanaman dalam keadaan ternaungi (Gang et al., 2001, Tan dan Nishida, 2012). Sintesis metabolit sekunder pada tanaman berasal dari bahan-bahan hasil metabolisme primer dan memerlukan ATP sebagai sumber energi (Hopkins dan Huner, 2008, Ncube dan Staden, 2015). Intensitas sinar matahari dan unsur hara yang tepat akan menghasilkan metabolisme primer yang optimal. Hal ini dibuktikan oleh hasil penelitian yang menunjukkan bahwa naungan $25 \%$ dan pupuk fosfat dosis $3.0 \mathrm{~g} \mathrm{SP} 36$ per tanaman memiliki bobot kering tertinggi sehingga mampu menghasilkan produksi minyak atsiri dan eugenol tertinggi pula.

Tabel 3. Bobot kering, produksi minyak atsiri dan eugenol tanaman akibat perlakuan naungan dan pupuk fosfat

\begin{tabular}{|c|c|c|c|c|}
\hline \multirow{2}{*}{ Naungan } & \multicolumn{4}{|c|}{ Pupuk SP36 (g) } \\
\hline & 0.0 & 1.50 & 3.0 & 4.5 \\
\hline \multicolumn{5}{|c|}{ Bobot kering tanaman $(\mathrm{g})$} \\
\hline Tanpa naungan & $74.10 \mathrm{~d}$ & $85.10 \mathrm{~cd}$ & $83.70 \mathrm{~cd}$ & $93.70 \mathrm{~cd}$ \\
\hline Naungan $25 \%$ & $138.10 \mathrm{ab}$ & $135.00 \mathrm{ab}$ & $147.70 \mathrm{a}$ & $110.00 \mathrm{bc}$ \\
\hline BNT 5\% & \multicolumn{4}{|c|}{28.52} \\
\hline \multicolumn{5}{|c|}{ Produksi minyak atsiri (g per tanaman) } \\
\hline Tanpa naungan & $0.61 \mathrm{f}$ & $1.23 \mathrm{e}$ & $1.23 \mathrm{e}$ & $1.43 \mathrm{~d}$ \\
\hline Naungan $25 \%$ & $1.20 \mathrm{e}$ & $2.02 \mathrm{~b}$ & $2.32 \mathrm{a}$ & $1.71 \mathrm{c}$ \\
\hline BNT 5\% & \multicolumn{4}{|c|}{0.102} \\
\hline \multicolumn{5}{|c|}{ Produksi eugenol (g per tanaman) } \\
\hline Tanpa naungan & $0.46 \mathrm{f}$ & $0.97 \mathrm{e}$ & $1.01 \mathrm{e}$ & $1.18 \mathrm{~d}$ \\
\hline Naungan $25 \%$ & $0.94 \mathrm{e}$ & $1.64 b$ & $1.92 \mathrm{a}$ & $1.41 \mathrm{c}$ \\
\hline BNT 5\% & \multicolumn{4}{|c|}{0.075} \\
\hline
\end{tabular}

Keterangan: Angka-angka yang diikuti huruf yang sama menunjukkan tidak berbeda nyata berdasarkan uji BNT 5\%.

\section{KESIMPULAN}

Interaksi perlakuan naungan $25 \%$ dan pupuk fosfat 3.0 g SP36 per tanaman memberikan nilai tertinggi pada bobot kering, produksi minyak atsiri, dan eugenol per tanaman.
Naungan 25\% memberikan nilai tertinggi pada variabel tinggi tanaman, luas daun, dan bobot basah total tanaman. Perlakuan pupuk fosfat $3.0 \mathrm{~g}$ SP36 per tanaman memberikan nilai tertinggi pada kandungan klorofil (klorofil b dan klorofil total). 


\section{DAFTAR PUSTAKA}

Agusta, A. 2006. Diversitas jalur biosintesis senyawa terpena pada makhluk hidup sebagai target obat antiinfektif. Berita Biologi 8:141-152.

Cheng, L., X. Tang, C.P. Vance, P.J. White, F. Zhang, J. Shen. 2014. Interaction between light intensity and phophorus nutrition affect the phosphate-mining capacity of white lupin (Lupinus albus L.). J. Exp. Bot. 65:2995-3003.

Devkota, A., P.K. Jha. 2010. Effects of different light level on the growth traits and yield of Centella asiatica. Middle-East J. Sci. Res. 5:226-230.

Ekawati, R., A.D. Susila, J.G. Kartika. 2010. Pengaruh naungan terhadap pertumbuhan dan produktivitas beberapa tanaman sayuran indigenous. J. Hort. Indonesia 1:46-52.

Feijo, E.V.R.S., R.A. Oliveira, L.C.B. Costa. 2014. Light affects Varronia curassavica essential oil yield by increasing trichomes frequency. Rev. Bras. Farmacogn 24:516-523.

Gang, D.R., J. Wang, N. Dudareva, K.H. Nam, J.E. Simon, E. Lewinsohn, E. Pichersky. 2001. An investigation of the storage and biosynthesis of phenylpropenes in sweet basil. Plant Physiol. 125:539-555.

Hadipoentyanti, E., S. Wahyuni. 2008. Keragaman selasih (Ocimum spp) berdasarkan karakter morfologi, produksi dan mutu herba. J. Littri. 14:141-148.

Hani, M.H., S.A.H.A.S. Mohamed, M.H. Mursy, W. Ngesimana, P.N. Mudau. 2015. Yield and essential oil response in coriander to water stress and phosphorus fertilizer application. TEOP. 18:82-92.

Harborne, J.B. 1987. Metode Fitokimia Penuntun Cara Modern Menganalisis Tumbuhan. Penerbit ITB Bandung, ID.

Hopkins, W.G., N.P.A. Huner. 2008. Introduction to Plant Physiology $4^{\text {th }}$ edition. The University of Western, Ontario, CA.

Kardinan, A. 2009. Penggunaan selasih dalam pengendalian hama lalat buah pada mangga. J. Littri. 15:101-109.

Khair-ul-Bariyah, S., D. Ahmed, M. Ikram. 2012. Ocimum bacilicum: A review on phytochemical and pharmacological studies. Pak. J. Chem. 2:78-85.
Kisman, N. Khumaida, Trikoesumaningtyas, Sobir, D. Soepandie. 2007. Karakter morfo-fisiologi daun, penciri adaptasi kedelai terhadap intensitas cahaya rendah. Bul. Agron. 35:96-102.

Khrolenko, Y., O. Burundukova, E. Burkovskaya, Y. Zhuravlev. 2012. Mesophyll structure and chloroplast density in panax ginseng leaves from the shikote-alin mts. Acta Biol. Cracoviensia Series Bot. 54:54-60.

Li, T., L. Liu, C. Jiang, Y. Liu, L. Shi. 2014. Effect of mutual shading on the regulation of photosynthesis in fieldgrown sorghum. J. Photochem. Photobiol. B. 137:3138.

Musyarofah, N., S. Susanto, S.A. Aziz, S. Kartosoewarno. 2007. Respon tanaman pegagan (Cantella asiatica L. Urban) terhadap pemberian pupuk alami di bawah naungan. Bul. Agron. 35:217-224.

Naseri, R., A. Mirzaei, K. Nazanalizadeh, A. Soleymanifard, A. Abravesh. 2011. Effect of different nitrogen and phosphorus application on qualitative and quantitative characteristic of beebalm. Planta Med. 12:1290-1293.

Ncube, B., J. V. Staden. 2015. Tilting plant metabolism for improved metabolite biosynthesis and enhance human benefit. Molecules 20:12698-12731.

Suntoro, H. Widijanto, Sudadi, E.E. Sambodo. 2014. Dampak abu vulkanik erupsi Gunung Kelud dan pupuk kandang terhadap ketersediaan dan serapan magnesium tanaman jagung di tanah alfisol. J. Ilmu Tanah Agroklimatologi 11:69-76.

Taiz, L., E. Zeiger. 2006. Plant Physiology, fourth edition. Sinaueur Associates. Sunderland, MA.

Tan, K.H., R. Nishida. 2012. Methyl eugenol: Its occurence, distribution and role in nature, especially in relation to insect behavior and pollination. J. Insect Sci. 12:174.

Wahyuni, S., E. Hadipoentyanti, A. Kardinan. 2005. Karakteristik morfologi dan kandungan minyak dua nomor selasih hutan (Ocimum gratissimum L.). Bul. Littro. 16:10-17.

Xu, H.X., X.Y. Weng, Y. Yang. 2007. Effect of phosphorus defiency on the photosynthetic characteristic of rice plant. Russian J. Plant Physiol. 54:741-748. 